\title{
Comparison of Thyrotropin Receptor Antibodies Levels Before and After Methimazole Therapy for 6 months in Children With Graves Disease Satrio Bhuwono Prakoso ${ }^{\mathrm{a}}$, Karina Sugih Arto ${ }^{\mathrm{b}}$, Lily Irsa ${ }^{\mathrm{c}}$
}

adoktersatrio@yahoo.com

aPediatric Resident, Child Health Departement, Faculty of Medicine,University of North Sumatra, Medan,Indonesia ${ }^{\mathbf{b}}$ Endocrinology Pediatric Consultant, Child Health Departement, Faculty of Medicine,University of North Sumatra, Medan-Indonesia

${ }^{\mathbf{c}}$ Immunology Pediatric Consultant, Child Health Departement, Faculty of Medicine,University of North Sumatra, Medan-Indonesia

\begin{abstract}
Background : Graves' disease is the leading cause of hyperthyroidism in children. The increase of hormones thyroxine (T4), free thyroxine (fT4) and triiodothyronine (T3) in Graves' disease is caused by the presence of thyroid stimulating antibodies (TSHR-Ab) or Thyrotopin receptor antibodies (TRAb). Methimazole (MMI) is often use as anti thyroid medication in children. Methimazole therapy may give a good response to patients with new-onset Graves' disease, high levels of thyroxine, high TRAb), and no or small goiters.

Objective : The purpose of this study was to determine the differences in TRAb before and after Methimazole Therapy for 6 months in children with Graves' disease.

Method : Retrospective study on 28 children below 18 year old with Graves' disease at H. Adam Malik General Hospital Medan with TRAb, fT4, TSH data collection before and after Methimazole therapy for 6 months taken from medical records. Result : Median age $11.85 \pm 3.73$ with the number of women $85.7 \%$ compared to men $14.3 \%$. The median value before Methimazole therapy was TRAb 32,11 IU/L, fT4 $3.56 \mathrm{ng} / \mathrm{dl}$ and TSH $0.01 \mathrm{mU} / \mathrm{l}$. Median values after 6 months of Methimazolee therapy were TRAb $17.15 \mathrm{IU} / \mathrm{L}$, fT4 $1.51 \mathrm{ng} / \mathrm{dl}$ and TSH $0.51 \mathrm{mU} / \mathrm{l}$ with $\mathrm{P}$ values $<0.001, \mathrm{P}=0.006, \mathrm{P}<0.001$ respectively.

Conclusion: There was significant differences in TRAb, fT4, and TSH median values before and after 6 months of Methimazole therapy in children with Graves' disease.
\end{abstract}

Keywords : Thyroid;Hyperthyroidism;Graves disease;TRAb;fT4;Methimazole

\section{Introduction}

Hyperthyroidism is a rare disease in children, with an annual incidence of 8 per 100,000 in children younger than 15 years, and 1 per 100,000 in children under 4 years.[1] Graves' disease is the most common cause of hyperthyroidism in children, responsible for $84 \%$ of all hyperthyroid disease. In the United States the incidence oreach 0.1-3 in 100,000 children with a prevalence of 1 in 10,000 children. [2,3] The incidence of Graves' disease increases with age and often found at the age of 10-15 years and more common in women than men with a ratio of 4:1 to 7:1 where families with autoimmune diseases increase the risk of Graves' disease by $60 \%$. [3,4]

The increased production of thyroxine (T4), free thyroxine (fT4) and triiodothyronine (T3) hormones is caused by the presence of Thyroid Stimulating Antibody (TSHR-Ab) or Thyroid Hormone Receptor Antibody (TRAb) which are part of the immunoglobulin subclass G1. Thyroid Hormone Receptor Antibody will stimulate Thyroid Stimulating Immunoglobulin (TSI) which will promote synthesis and activity of sodium-iodium 
symporter, causing thyroid hormone hypersecretion, hypertrophy and follicular hyperplasia which will form diffuse goiter even in the absence of Thyroid Stimulating Hormone.[1]

Anti-thyroid medication was discovered in 1940 and the first drug that used was Propylthiouracil (PTU), but now the drug that often used in children is Methimazole (MMI).[5] The response to methimazole or radioiodine therapy for Graves' disease can be assessed by a decrease in TSI levels which correlates with an increase in Thyroid Stimulating Hormone (TSH) levels.[5] Studies in the adult population concluded that in patients with new-onset Graves' disease, high thyroxine levels, high thyrotropin binding inhibitory immunoglobulin (TBII), and absence or low goiter have responded well to methimazole therapy.[6] Other studies have shown that initial TRAb levels are better predictive of remission in Graves' disease.[7] In children, there is no or small goiter, low TRAb levels at initial diagnosis, and TRAb normalization time below 1 years also indicates a good prognosis for achieving remission.[8]

\section{Materials and methods}

\section{Study Design}

This study is an observational analytic study with a retrospective design and aim to find out the comparison between TRAb levels before Methimazole therapy and after Methimazole therapy after 6 months. The study was conducted on patients with Graves' disease in children undergoing therapy at Adam Malik Hospital, Medan, North Sumatera Indonesia from March 2018 - March 2021. This study received permission from the Research Ethics Commission of the University of North Sumatra, Indonesia.

\section{Subject}

This study examined 28 people who came for treatment to the Pediatric Endocrinology polyclinic of Haji Adam Malik General Hospital with hyperthyroidism and were treated with MMI. Subjects who met the inclusion and exclusion criteria and had been examined for TRAB, TSH, fT4 Chemiluminescent Microparticle Immunoassay (CMIA) using the Architect tool. Datas from before therapy and every month for 6 consecutive months were taken through medical records.

Inclusion Criteria: Patients with Graves' disease aged <18 years and patients with Graves' disease treated with Methimazole for 6 months. 
Exclusion criteria: Patients had complications such as heart failure, thyroid storm, received glycocorticoid therapy or drugs that can affect thyroid hormone work, (loss to follow-up), and had received previous therapy with anti-thyroid drugs.

\section{Statistical Analysis}

The datas analyzed statistically with SPSS (Statistical Product and Science Service) version 24. Demographic characteristics of patients with Graves' disease were analyzed with descriptive analysis. The comparison between levels of TRAb, fT4 and TSH before Methimazole therapy and after Methimazole therapy after 6 months were analyzed by paired t-test if the datas were normally distributed or alternative Wilcoxon test if the data were not normally distributed. the datas were significance 1 if the $p$ value $>0.05$.

\section{Result and findings}

There were 59 people who came for treatment to the Pediatric Endocrinology clinic of Haji Adam Malik General Hospital with hyperthyroidism which were then excluded because of 1 subject with Thyroid Storm and heart problems, 2 subjects with Hashimoto's disease, 1 subject with thyroid tumor and 27 subjects who were not routinely control or loss to follow up. After passing the selection of exclusion and inclusion criteria, this study was finally followed by 28 research subjects who had been diagnosed with Graves' disease (figure 1). The majority of the research subjects were women as many as 24 people (85.7\%) and men as many as 4 people (14.3\%). The mean age of the subjects in this study was 11.85 years. There was no history of thyroid and autoimmune disease in all subjects. (Table 1)

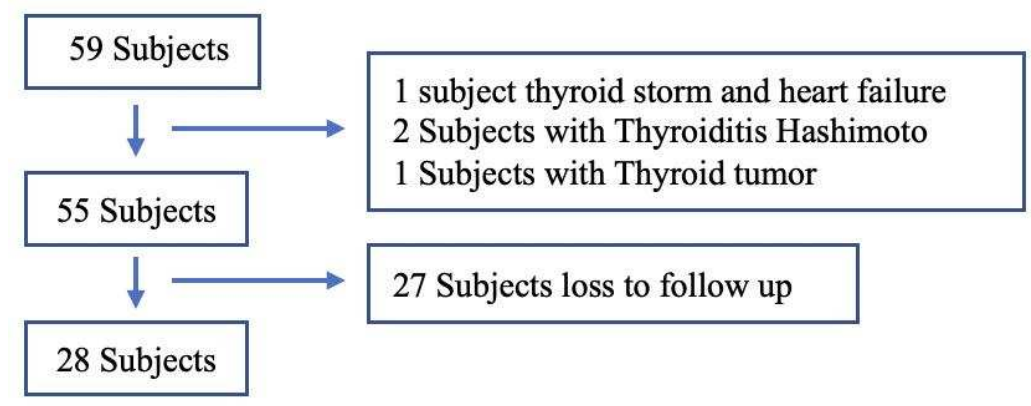

Fig. 1 Subjects 
Table. 1 Charateristic of Subjects

\begin{tabular}{lc}
\hline Characteristic & $\mathrm{n}=28$ \\
\hline Age, (Year) & $11,85 \pm 3,73$ \\
Sex, $\mathrm{n}(\%)$ & $4(14,3 \%)$ \\
Men & $24(85,7 \%)$ \\
Woman & $37.78 \pm 13.37$ \\
Weight $(\mathrm{kg})$ & $1.48(0.86-1.71)$ \\
Height $(\mathrm{m})$ & $18.15 \pm 3.50$ \\
Body mass index $\left(\mathrm{kg} / \mathrm{m}^{2}\right)$ & \\
Family history with thyroid disease & $0(0 \%)$ \\
Yes & $28(100 \%)$ \\
No & \\
Family history with autoimmune disease & $0(0 \%)$ \\
Yes & $28(100 \%)$ \\
No & \\
Exophtalmus & \\
Yes & $24(85,7 \%)$ \\
No & $4(14,3 \%)$ \\
\hline
\end{tabular}

The median TRAb, fT4, and TSH level in patients with Graves' disease before Methimazole therapy (32.11 IU/L), (3.56 ng/dl), $0.01 \mathrm{mU} / \mathrm{l})$ was higher than the median TRAb level in Graves' disease patients after 6 months of Methimazole therapy (17.15 IU/L), (1.51 ng/dl), (0.51 mU/l) respectively. Decrease in TRAb and fT4 levels after 6 months of Methimazole therapy which was statistically significant with $\mathrm{p}$ value $<0.001,0.006$ respectively. Increase in TSH levels after 6 months of Methimazole therapy which was statistically significant with $\mathrm{p}$ value $<0.001$. (Table 2$)$ 
Table. 2 Comparison of TRAb,fT4 and TSH levels before Methimazole therapy and after 6 months of Methimazole therapy

\begin{tabular}{|c|c|c|c|c|}
\hline Value & & Before therapy & After 6 months therapy & $P$ value \\
\hline \multirow[t]{2}{*}{ TRAb (IU/L) } & $\begin{array}{l}\text { Mean } \pm \text { Standard } \\
\text { deviation }\end{array}$ & $27,95 \pm 13,21$ & $17,87 \pm 17,15$ & \\
\hline & Median (min-max) & $32,11(1,95-40,0)$ & $17,15(1,61-39,27)$ & $<0,001$ \\
\hline \multirow[t]{2}{*}{ fT4 (ng/dl) } & $\begin{array}{l}\text { Mean } \pm \text { Standard } \\
\text { deviation }\end{array}$ & $4,76 \pm 6,48$ & $3,40 \pm 6,86$ & \\
\hline & Median (min-max) & $3,56(0,77-36,19)$ & $1,51(0,49-34,70)$ & 0,006 \\
\hline \multirow[t]{2}{*}{ TSH (mU/l) } & $\begin{array}{l}\text { Mean } \pm \text { Standard } \\
\text { deviation }\end{array}$ & $0,05 \pm 0,16$ & $2,13 \pm 8,23$ & \\
\hline & Median (min-max) & $0,01(0,00-0,65)$ & $0,51(0,01-43,97)$ & $<0,001$ \\
\hline
\end{tabular}

\section{Discussion}

Characteristic data in this study showed the proportion of female sex was 24 people (85.7\%) and male as many as 4 people $(14.3 \%)$. Other data from other sources show the same thing where women can be 4 to 7 times more often affected by Graves' disease than men. [9,10] This may be related to higher levels of estrogen and progesterone receptors and higher levels of the hormone estrogen. which can be a risk factor for Graves' disease due to the stimulation of gene expression for this disease. The dominance of estrogen over progesterone will increase the incidence of autoimmune, including Graves' disease.[11]

The median value of the age of the subjects in this study was 11.83 years. This is in accordance with the peak incidence of Graves' disease in the adolescent age range, especially 10-15 years. [3,12] Graves' disease is more common in adults than in children and adolescents. The incidence in adults can reach 24.8 cases. $/ 100,000$ people.[13]

There was no family history of autoimmune and thyroid disease in the study subjects. Research in the UK has shown that graves are associated with a family history of thyroid disease. No family history of thyroid disease can also be a good indicator for managing more rapid remission.[14]

The subjects of this study found a body mass index of only $18.15 \pm 3.50 \mathrm{~kg} / \mathrm{m} 2$, which indicated that $82 \%$ of subjects had a normal body mass index, $7 \%$ a low body mass index, and $11 \%$ a high body mass index or 
overweight. Low body mass index is associated with relapse in children with Graves' disease undergoing therapy, whereas high body mass index is associated with earlier remission.[15.16]

Exophthalmos was found in $85.3 \%$ of subjects with TRAb values above 10 IU/L compared to patients without exophthalmos with TRAb values below $10 \mathrm{IU} / \mathrm{L}$ which was only present in 4 patients. This is similar to a study in Lithuania that found that patients with Graves Ophthalmopathy had higher fT4 and TRAb values than those without Graves Ophthalmopathy.[17]

The median value of TRAb before therapy was $32.11 \mathrm{IU} / \mathrm{L}$ compared to the final value after 6 months of Methimazole therapy was $17.15 \mathrm{IU} / \mathrm{L}$ with a significant decrease (P Value $<0,001)$. A study found that low initial TRAb levels have a good prognostic value in the emergence of faster remission.15,39 This is in line with studies that found a high number of relapses with high TRAb levels at the time of initial diagnosis. [18]

The median initial fT4 level of research subjects was $3.56 \mathrm{ng} / \mathrm{dl}$, which was higher than the median value of fT4 levels in Graves' disease patients after 6 months of Methimazole therapy, which was $1.51 \mathrm{ng} / \mathrm{dl}$ which decreased significantly (P value 0.006). Low baseline T4 and T3 values are predictors of earlier remission in Graves' disease.[16] Studies in the pediatric population have also concluded that high levels of fT4 and TRAb at initial diagnosis are a risk factor for recurrence of Graves' disease.[19]

The median TSH level in this study before Methimazole therapy was $0.01 \mathrm{mU} / \mathrm{l}$ which was lower than the median TSH level after 6 months of Methimazole therapy, which was $0.51 \mathrm{mU} / 1$ which increased significantly (P Value <0.001). Administration of antithyroid drugs lowers TRAb which will increase TSH.60 In treated Graves' disease, elevated TSH levels can represent a good predictor of remission as well as decreased of TSI levels.[20]

\section{Conclusion}

In this study, more female subjects were $85.7 \%$, the median age was 11.83 years, the median body mass index was 18.15 , there was no history of thyroid and autoimmune diseases in the subject's family, and the dominant clinical exophthalmos in the subjects was $85 ., 7 \%$. There was significant difference between levels of TRAb, fT4, and TSH before and after Methimazole therapy for 6 months. 


\section{Conflict of Interest}

The authors declare that there are no conflicts of interest

\section{References}

1. Hanley P, Lord K, Bauer AJ. Thyroid Disorders in Children and Adolescents : A Review. JAMA Pediatr. 2016;170(10):1008-1019.

2. Bansal S, Umpaichitra V, Desai N, Perez-Colon S. Pediatric Graves’ Disease. Int J Endocrinol Metab Disord. 2015:1:1.

3. Cappa M, Bizzarri C, Crea F. Autoimmune Thyroid Diseases in Children. J Thyroid Res. 2010; 2011: 675703

4. Deliana M, Hakimi H, Batubara JRL. Hipertiroid. Within : AAP Batubara Jose RL, Bambang Tridjaja, Pulungan AB (Editor). Buku Ajar Endokrinologi Anak. Ed. 2. Jakarta:IDAI. 2018. p. 298-302.

5. Matshushita R, Nakagawa Y, Nagata E, Eiichiro S, Shinichiro S, Rie Y, et al. Initial Treatment of Pediatric Graves' Disease with Methimazole: A Retrospective Follow-up Study. Clin Pediatr Endocrinol. 2010:19(4),101-108.

6. Choi, Hoon Sung \& Won Sang, Yoo.Free Thyroxine, Anti-Thyroid Stimulating Hormone Receptor Antibody Titers, and Absence of Goiter Were Associated with Responssiveness to Methimazole in Patients with New Onset Graves' Disease. Endocrinol Metab. 2017:32(2):281-287.

7. Karmisholt, J., Andersen, S. L., Bulow-Pedersen, I., Carlé, A., Krejbjerg, A., \& Nygaard, B. Predictors of Initial and Sustained Remission in Patients Treated with Antithyroid Drugs for Graves' Hyperthyroidism: The RISG Study. Journal of Thyroid Research. 2019: 1-9.

8. Gastaldi, R., Poggi, E., Mussa, A., Weber, G., Vigone, M. C., Salerno, M., Corrias, A. Graves Disease in Children: Thyroid-Stimulating Hormone Receptor Antibodies as Remission Markers. The Journal of Pediatrics.2014. 164(5), 1189-1194.e1. doi:10.1016/j.jpeds.2013:12.047

9. Prita YN, Utari A, Batubara JRL, AAP Bambang T, Rustama SD, Pulungan AB, et al. Panduan Praktik Klinis Ikatan Dokter Anak Indonesia : Diagnosis dan Tata Laksana Hipertiroid. Editor : Prita YN, Utari A, AAP Bambang T. Jakarta : IDAI : UKK Endrokinologi. 2017.

10. D. Zimmerman and A. N. Lteif. Thyrotoxicosis in children. Endocrin Metab Clin. 1998: 27(1):109-126.

11. Domoslawski, Pawel, Podhorska-Okolow, Marzena, Pula, Bartosz, et al. Expression of estrogen and progesterone receptors and Ki-67 antigen in Graves' disease and nodular goiter. Folia histochemica et cytobiologica / Polish Academy of Sciences, Polish Histochemical and Cytochemical Society. 2013: 51:13540 .

12. Lavard L, Ranløv I, Perrild H, Andersen O, Jacobsen BB. Incidence of juvenile thyrotoxicosis in Denmark, 1982-1988. A nationwide study. Eur J Endocrinol. 1994 Jun. 130(6):565-8. 
13. McGrogan A, Seaman HE, Wright JW, de Vries CS. The incidence of autoimmune thyroid disease: a systematic review of the literature. Clin Endocrinol (Oxf). 2008 Nov;69(5):687-96.

14. Manji N, Carr-Smith JD, Boelaert K, Allahabadia A, Armitage M, Chatterjee VK, al. Influences of age, gender, smoking, and family history on autoimmune thyroid disease phenotype. J Clin Endocrinol Metab. 2006 Dec;91(12):4873-80.

15. 15.28 Lee HS, Hwang JS. The treatment of Graves' disease in children and adolescents. Ann Pediatr Endocrinol Metab. 2014:19(3):122-6.

16. 16.51 Nicole S. Glaser, Dennis M. Styne. Predictors of Early Remission of Hyperthyroidism in Children.J Clin Endocrinol Metab. 1997: 82(6)1: 1719-1726.

17. Jarusaitiene D, Verkauskiene R, Jasinskas V, Jankauskiene J. Predictive Factors of Development of Graves Ophthalmopathy for Patients with Juvenile Graves. Disease. Int J Endocrinol. 2016.

18. 18.54 Vitti P, Rago T, Chiovato L, Pallini S, Santini F, Fiore E, et al. Clinical features of patients with Graves' disease undergoing remission after antithyroid drug treatment. Thyroid. 1997:7(3):369-75.

19. Kaguelidou F, Alberti C, Castanet M, Guitteny MA, Czernichow P, Léger J; French Childhood Graves' Disease Study Group. Predictors of autoimmune hyperthyroidism relapse in children after discontinuation of antithyroid drug treatment. J Clin Endocrinol Metab. 2008 Oct;93(10):3817-26.

20. Udaya Kabadi and Bhartur Premachandra. Serum Thyrotropin in Graves' Disease: A More Reliable Index of Circulating Thyroid-Stimulating Immunoglobulin Level than Thyroid Function?. Endocrine Practice: October: 2007:13 (6): 615-619. 